\title{
EFFECT OF BODY WEIGHT AND SOME HORMONES ON EACH OF PRODUCTIVE AND IMMUNOLOGICAL PERFORMANCE OF TWO LOCAL LAYING HENS STRAINS
}

\author{
HASSAN, M. S. H., E.A. ABDALLAH and DOAA M. M. YASSEN \\ Animal Production Research Institute, ARC, Ministry of Agriculture, Giza, Egypt
}

(Manuscript received 26 November 2012)

\begin{abstract}
A total of 300 females from each of Sinai and Mamourah local laying hens (150 each) were used to study the relationship between body weight, thyroid hormones and Leptin hormone and their effects on productive, physiological and immunological performance. Birds of each strain were classified according to their body weight into three groups (high, medium and low). Each group of each strain containing 50 females was equally subdivided into 5 replicates for the experimental period (20- 40 weeks of age). Body weight and feed consumption were recorded every four weeks, egg production (egg number, egg weight and calculated egg mass) were detected daily. Also, egg quality traits were taken at the end of the experimental period. At the end of the experimental period, five birds / group were chosen randomly slaughtered and blood serum samples were collected to determine calcium , phosphorus, total protein , albumin , globulin , cholesterol, LDL, HDL, total lipids, glucose, Leptin , T3, T4 , LH and FSH hormones . Results indicated that : -Mamourah hens had significantly higher body weights and consumed the largest amount of feed compared with Sinai ones. - Age at sexual maturity was delayed for hens of low body weights compared with those for high and medium body weights for both chicken strains. - Medium body weight groups for both strains represented the highest numerical increase for egg weight and egg mass followed by the high weights and lastly the smallest ones. - Eggs produced from low body weight hens recorded significant increase in shell thickness and Haugh units compared with eggs for high body weight hens. Mamourah hens had a higher absolute and relative albumen weight than Sinai hens. - Levels of serum Leptin and thyroid hormones T3 and T4, calcium, phosphorus, total protein, albumin, globulin, LH and FSH hormones were increased in low and medium groups compared with high groups. - Levels of serum glucose, cholesterol, LDL, HDL and total lipids were decreased in low and medium groups compared with high groups. - The immune response against Newcastle and Avian Influenza diseases and spleen and

thymus relative weights were increased in low and medium groups compared with high groups. - There were positive correlations between body weight, egg weight and egg mass, but it was negative between body weight and egg number. Positive correlations between body weight, T3, T4 hormones, phosphorus and cholesterol were found. - There were negative correlations between body weight and Leptin, LH, FSH hormones and calcium. - Negative correlations between high levels of Leptin
\end{abstract}


hormone and T3, T4 hormones and cholesterol were found. - There were positive correlations between high levels of Leptin hormone and increasing levels of $\mathrm{LH}, \mathrm{FSH}$ hormones, calcium and phosphorus. It can be concluded that live body weight had an important role in regulating the release of some hormones which exert their effects on the productive performance of laying hens.

\section{INTRODUCTION}

In the production of meat, this goal is realized by breeding large bodies strains with a high proportion of desirable meat and little fat (Ricklefs, 1985).Body weight is an important indicator of general health and lighter birds on the average produce the lowest meat and egg mass (Singh and Nordskog, 1982).Blood biochemical and hematological characteristics could be very important as indicator traits in breeding for highest productive performance birds (Hassan et al ., 2006 and Hassaan et al., 2009).

Several studies in mammals have shown a relationship between obesity, plasma Leptin concentrations and reproduction (Foster and Nugatani, 1999).

Although excessive body weight and fat deposition have been advanced as being the case or reduced reproductive performance, the physiological mechanisms by which these parameters affect reproduction remains unexplainable, recent evidence suggests that chicken liver and fat cells express the Leptin gene (Ashwell et al., 1999).

Christos and Stergios (1998) showed that the biology of Leptin secretion and regulation, as well as our current knowledge of the role Leptin plays in various physiological and pathophysiological states in the poultry.

Bruggeman et al. (2007) found that age at first egg (day) was nearly related to the low level of Leptin with high body weight, high fat weight $\%$ and low liver weight $\%$ and the positive correlation between liver weight and Leptin concentrations suggests that the liver may be a major source of Leptin in laying hens .

The hormone Leptin is a highly conserved 167- amino acid protein that is encoded by the obese (ob) gene and it is predominantly, although not exclusively, synthesized by adipose tissues and it circulates in the plasma in amounts proportional to body fat content. (Jenni, 2007).

Leptin displays a high degree of homology amongst different species and it is also analogous in structure to other cytokines and it was first identified by its ability to regulate feed intake and body weight via its actions in the hypothalamus (Spiegelman and Flier, 2001). Moreover, Cassy et al. (2004) reported that Leptin hormone played an important role on feed consumption and control organization of ovulation operations for poultry. 
Ashwell et al. (1999) and Kuo (2003) showed that Leptin was an important hormone for regulation some hormones functions i.e. Leptin play a role in conversion of T4 hormone to T3 hormone in broilers. Tina et al. (2003) found that relationship between Leptin, thyroid hormones and regulation of biosynthesis and metabolism in body, control on body composition and productive and physiological performance for laying hens.

The physiological and heamatological parameters are good indicator to predict and estimate productive and reproductive performance in chickens (Emmerson, 2003).

The goal of this study was to throw a light on the relationship between body weight, Leptin and thyroid hormones and their effects on productive, physiological and immunological performance in two local laying hens with different body weight.

\section{MATERIALS AND METHODS}

This study was carried out at Al-Serw Poultry Station, Animal Production Research Institute, Agricultural Research Center, Giza, Egypt.

One hundred and fifty pullets aged 20 wk- old from each of Sinai and Mamourah local strains were used in this study. Birds were housed separately in an open system. All birds were reared under the same environmental and managerial conditions during the experimental period (20-40 weeks of age). They were fed diet containing $16 \%$ crude protein ,2650 Kcal ME / Kg diet , $0.40 \%$ available phosphorus and $1.0 \%$ calcium from 20- 24 weeks of age and fed diet containing 17\%crude protein ,2720 Kcal ME / Kg diet , $0.45 \%$ available phosphorus and $3.3 \%$ calcium from $24-40$ weeks of age.

\section{Classification of Strains}

At 20 week of age, all females of each strain were weighed and classified according to the body weight into three groups (50 females per each) (Table 1).

(1) The first group represented high body weight $(H)$ where live body weights of Sinai strain were over $1300 \mathrm{~g}$. and Mamourah ones were over $1500 \mathrm{~g}$.

(2) The second group of medium body weight (M) where live body weight of Sinai strain ranged from 1200 to $1300 \mathrm{~g}$. and Mamourah ones ranged from 1400 to $1500 \mathrm{~g}$.

(3) The third group of light body weight (L) where live body weights of Sinai strain were under $1200 \mathrm{~g}$. and Mamourah ones were under $1400 \mathrm{~g}$.

Each group for each strain was subdivided into 5 replicates, each of 10 females. 
Table 1. Classification of chicken strains according to average body weight at 20 weeks of age.

\begin{tabular}{|c|c|c|c|c|c|c|c|}
\hline Parameter & Age & \multicolumn{4}{|c|}{ Sinai } & \multicolumn{3}{c|}{ Mamourah } \\
\cline { 3 - 8 } & (week) & $\mathrm{H}$ & $\mathrm{M}$ & $\mathrm{L}$ & $\mathrm{H}$ & $\mathrm{M}$ & $\mathrm{L}$ \\
\hline Body & & ${ }^{1372.80^{\mathbf{b}}}$ & $1276.92^{\mathbf{c}}$ & $1151.55^{\mathbf{d}}$ & $1583.86^{\mathbf{a}}$ & $1464.70^{\text {ab }}$ & $1367.27^{\mathbf{b}}$ \\
weight & 20 & \pm 3.73 & \pm 3.81 & \pm 3.68 & \pm 3.92 & \pm 3.85 & \pm 3.81 \\
(g) & & & & & & & \\
\hline
\end{tabular}

$* a, b, c$ and $d$ Means \pm standard deviation in the same row with different letters, differ significantly

$(P \leq 0.05)$.

\section{Productive Performance}

Body weight by grams (B.W) and feed consumption (g/ hen/ day) (F.C) were recorded every four weeks through the whole experimental period. Age and body weight at sexual maturity, first egg weight, egg number (E.N), egg weight to the nearest $0.1 \mathrm{~g}$ (E.W) and egg mass (E.M) were recorded. At the end of the experimental period (40weeks of age), 30 eggs from each group were taken for detecting egg quality traits such as shape index, yolk index, yolk, albumen and shell weights and percentages, shell thickness $(\mathrm{mm})$ and Haugh units.

\section{Physiological Parameters}

\section{Serum constituents}

At 40 weeks of age, five laying hens from each group and strain were randomly chosen, weighed, slaughtered and blood samples were collected in sterile heparinzed centrifuge tubes. The samples were then centrifuged for $20 \mathrm{~min}$. at 3000 rpm. and serum samples were stored at $-20^{\circ} \mathrm{C}$ until analyzed for calcium, phosphorus, total protein, albumin , globulin, cholesterol , LDL, HDL , total lipids , glucose, Leptin , T3, T4, LH and FSH hormones using kits supplied by Daimmond Diagnostic ( Giza , Egypt ), at Animal Production Research Institute and Animal health Research Institute laboratories . Birds were eviscerated and carcass traits and liver, heart, kidney, gizzard, abdominal fat, thymus and spleen were weighed to nearest $0.1 \mathrm{~g}$ and estimated as relative organs weights (organ weight /live body weight $\times 100)$.

\section{Immunological estimations}

At the end of experimental period, hemagglutination - inhibition (HI) test was applied for determination of antibodies response in plasma samples according to OIE manual (2005). After 4 weeks of age immunization of the flock by Lasota vaccine against Newcastle Disease Virus (NDV) and against Avian Influenza Disease Virus (AIDV), Commercial ELISA Kits was used for detection the antibodies against 
nucleoprotein and matrix antigens of NDV and AIDV (Biockek B.V, Gouda and Holland). Hemagglutination- inhibition $(\mathrm{HI})$ test titers ranged as positive if there is inhibition at a serum dilution of $1 / 10(4 \log 2)$.

\section{Statistical Analysis}

Data were subjected to computerize two- way ANOVA analysis of variance and Duncan's multiple range test procedures using SAS (2000). The percentage values were transferred to percentage angle using arcsine equation before subjected to statistical analysis. In addition correlations between studied various parameters were calculated.

\section{RESULTS AND DISCUSSION}

\section{- Productive Traits}

\section{- Body weight}

Body weights for Sinai and Mamourah hens from 24 to 40 weeks old are represented in Table 2. Generally, this table shows that hens of Mamourah strain within the same category of weight classification have heavier weights compared with those of Sinai strain. Also, hens of low weight for Mamourah hens represented significant $(P \leq 0.05)$ heavier weights compared with that of low weight group for Sinai strain among all experimented ages. Whereas, hens of Mamourah strain for both high and medium weight have numerical heavier weight comparable to the same weight for Sinai hens at all ages except that of the significant differences which observed for medium weights at $24-48$ weeks of age.

These results agree with those of Marie et al. (2009) and Kosba and AbdEl-Halim (2008) who found that Mamourah strain recorded the heaviest body weight, while Sinai strain recorded the lightest one compared with Silver Montazah and Gimmizah strains and other local laying hen strains during a period from 24 to 44 weeks of age.

\section{- Feed consumption}

Data in Table 2 showed that hens with high and medium body weights for Sinai strain significantly $(P \leq 0.05)$ consumed larger amount of feed $(g /$ hen /day) compared with those for low body weights through the periods between 24 to 40 weeks of age.

While, this observation is true only for Mamourah strain between high and low groups of weight at the same mentioned age periods. Generally, Mamourah hens consumed more amount of feed than Sinai ones for the same age periods.

These results are agree with those of Marie et al. (2009) who reported that Gimmizah, Silver Montazah and Mamourah strains represented higher significant 
$(P \leq 0.05)$ increase of feed consumption ( $g /$ hen /day), respectively compared with Sinai strain, but Sinai strain has the best feed consumption compared with the other strains.

\section{- Egg production traits}

Results in Table 3 demonstrated that age at sexual maturity was significantly delayed for birds of low body weight groups of Sinai and Mamourah chicken strains (178.4 and 173.7 days ) than those for medium weights ( 172.1 and 168.9 days) and those for high body weight ones (170.1 and 166.1 days), respectively . This may be due to that the hens with high body weights reach to the physiological maturity earlier than the smallest weight hens.

Data in Table 3 showed that both high and medium body weight groups represented significantly $(P \leq 0.05)$ higher body weight at sexual maturity for each strain and laid significantly larger first egg than the low body weight ones, respectively.

Results in Table 4 declared that egg weight at all periods showed generally the similar trend of first egg weight, in which eggs weights increased significantly $(P \leq 0.05)$ in both the groups of high and medium body weights groups than the low body weights ones and egg weight was higher in Mamourah strain than Sinai strain in all periods .

Concerning egg number, it is clear from Table 4 that the low body weights hens laid fewer eggs during all periods compared with the medium body weights ones, while the groups of medium body weights laid significantly more eggs than the high body weights ones.

Table 4 showed that the medium group in the two strains were given the high significant in egg number and egg mass compared with other groups, Mamourah strain was give the high egg number and egg mass compared with Sinai strain.

These results agree with those of Marie et al. (2009) who reported that Gimmizah, Silver Montazah and Mamourah strains represented higher significant $(P \leq 0.05)$ increase of egg production, respectively compared with Sinai strain .

Also, Kosba and AbdEI-Halim (2008) found that Mamourah strain recorded the heaviest egg weight and egg mass, while Sinai strain recorded the lightest one compared with other local laying hen strains as compared at 24 to 44 weeks of age.

\section{- Egg quality}

It can be observed from Table 5 that some egg quality traits such as egg shape index, yolk index, egg weight ( $g$ ), egg shell weight $(g)$ and shell weight \% were not significantly affected either by chicken strain or body weight. High body weight for Mamourah strain represented a highly significant increases for albumen 
weight compared with those produced hens with low body weights for both Sinai and Mamourah strains.

Also, there were significant differences between albumen weight percent for eggs produced from classified weights for Sinai strain, while, high and medium body weights for Mamourah strain represented significant increase of albumen weight percent compared with those for low weight. Regarding shell thickness, both chicken strains represented the same trend as it significantly $(P<0.05)$ increased for eggs produced from medium and low body weights compared with those for high body weight group. It means that egg shell thickness increased with the decrease of egg weight. Moreover, low body weight for both strains represented the highest significant increase of Haugh units compared with those for eggs produced from high and medium body weight groups except those for medium size of Sinai strain. Irrespective to chicken strain, low and medium body weight hens significantly produced thicker eggshell compared with those from the high body weight group. These results in accordance with those reported by El- Labban (2000) who found that Golden Montazah and Mandarah strains had higher values of albumen weight and albumen index, while Silver Montazah and Matrouh strains had lower values and he found different values between four local strains in albumen weight and albumen index. Besides, Hanafi and Obeidah (1984) found that small egg breeds were characterized with thicker shell than large egg breeds.

\section{- Physiological parameters}

Table 6 shows clearly that birds with low body weight for both chicken strains represented higher significant $(P<0.05)$ increase of Leptin hormone $(\mathrm{ng} / \mathrm{ml}$ ) compared with those for high body weight, while the difference with medium size was significant only for Sinai strain but not for Mamourah. Reverse trends were observed with T3 and T4 hormones as they significantly decreased according to the decrease of body weight from high to low sizes, while the medium body weight represented the intermediate value for both strains. Moreover, low body weight had a higher significant increase of T3 /T4 ratio, $\mathrm{LH}$ (IU/ ml) and FSH (IU / ml) hormones compared with those for high ones, whereas the medium size represented the intermediate values for both strains.

Generally, LH and FSH hormones for Sinai and Mamourah strains showed the same trend of increase with the decrease of body weights from high to medium and low as observed in leptin hormone values, while thyroid hormone values had an opposite trend.

These results are in accordance with findings of Bruggeman et al. (2007) who divided the broiler breeder females to high, medium and low groups according to the 
body weight and they found negative correlation between body weight and Leptin concentration.

The increase of feed consumption for high body weight birds as demonstrated in Table 2 could be explained on the light of Leptin hormone decrease in this group (Table 6). This result is supported by Cassy et al. (2004) who mentioned that Leptin hormone plays an important role in affecting feed consumption. In addition, Tina et al. (2003) found a relationship between Leptin, thyroid hormones and regulation of biosyntheses and metabolism in body, control of body composition and productive and physiological performance for laying hens. Moreover, Kuo (2003) showed the important role of Leptin hormone for regulation of some hormones as Leptin plays a role in conversion of T4 hormone to T3 hormone in broilers.

Results in Table 7 showed that levels of serum calcium, phosphorus, total protein, albumin and globulin were highest in the low body weight birds followed by the medium group and the lowest ones in the high body weight group for both strains. The significant differences between low and high weights were observed in calcium and phosphorus values for Sinai strain and total protein, albumen and globulin for Mamourah strain.

The values of these parameters represented the same trend of Leptin hormone increase with the decrease of body weight as shown in Table 6. Whereas, glucose, cholesterol, LDL, HDL and total lipids had significantly $(P<0.05)$ decreased for low body weight group compared with those for high body weight group, while these parameters were intermediate in the medium body weight group for Sinai and Mamourah strains. Different authors mentioned the relation between Leptin hormone and the physiological parameters as stated in current study. Christos and Stergios (1998) showed that the biology of Leptin secretion and regulation, and the role which Leptin plays in various physiological and pathophysiological states in the poultry. Also, Spiegelman and Flier (2001) showed that Leptin displays a high degree of homology amongst different species and it is also analogous in structure to other cytokines and it was first identified by its ability to regulate feed intake and body weight via its actions on the hypothalamus.

\section{- Immune Response}

\section{- Against Newcastle Disease Virus (NDV) and Avian Influenza Disease Virus (AIDV):}

As shown in Table 8, both chicken strains represented the same trend of immune response increase against NDV and AIDV according to body weight with one exception. Highest significant $(P<0.05)$ records for antibody titers against NDV and AIDV for both chicken strains were recorded for hens with low body weight compared 
with either high or medium sizes except Sinai strain which did not represent any significant difference with respect to AIDV between low and medium sizes. It means that increasing the antibody titter for both vaccines against NDV and AIDV could be related to the decrease of body weight and the increase of Leptin hormone as shown in Table 6. These results are keeping with those reported by Cassy et al. (2004) who mentioned that Leptin hormone plays an important role in formation of hematopoiesis, granulocytes and macrophages and control organization of activating red blood cells formations in poultry.

In conclusion, the increase of serum immune globulin levels in low body weight birds could be related with the increase of Leptin level which in turn could help immune response increase against other infectious poultry diseases.

\section{- Immune related organ weights}

Data in Table 9 showed that the low body weights groups had a significant increase for spleen and thymus relative weights than other groups in Sinai and Mamourah strains. This result could be related to the data of immune response in Table 8 which represented the increase of immune response against NDV and AIDV in low body weight birds for Sinai and Mamourah strains.

It is worse to mention that available references in this regard are scarce.

\section{-Some internal organ weights}

Table 9 shows that high body weight hens had significantly $(P \leq 0.05)$ higher increase compared with those for low body weight with respect to live body weight and carcass weight for both strains, whereas these traits for the medium weight hens were intermediate.

Also, liver weight percent was significantly increased for low body weight hens compared with those for high body weight ones for each chicken strain, Moreover this significant increase was observed comparing with those for medium weight of Mamourah strain and not for Sinai ones. Kidney relative weights were significantly higher for both high and medium weights compared with those for low body ones for each experimented strain. Gizzard and abdominal fat relative weights were significantly highest for high weight hens followed by medium and finally the low ones with the same significant difference for both strains. Spleen and thymus percents in the same Table represented the same trend of significant decrease with body weight increase in both strains except that between high and medium weight of Mamourah strain.

These results confirm the findings of Bruggeman et al (2007) who found that low level of Leptin with high body weight, high fat weight $\%$ and low liver weight $\%$ and the positive correlation between liver weight and Leptin concentrations suggests that 
the liver may be a major source of Leptin in chickens, also Leptin is found in fat tissue of mammals and chickens, but in chickens it is also found in the liver.

\section{- Correlation coefficients between body weight, some productive and physiological parameters}

Correlations between body weight, some productive and physiological performance traits are very useful for improvement these traits and gave knowledge about relations of productive and physiological performance traits beside it is very importance over phenotype and genetic correlation in selection program's in laying hens.

The correlation coefficients (Table 10) between body weight, some productive and physiological performance traits revealed that, there were a high positive correlation between B.W and both of E.W and E.M $(P<0.01)$. Also, there was a high positive correlation between E.W, E.N and E.M, whereas, the negative correlation $(P<0.01)$ was found between B.W and E.N and between E.N and E.M.

Moreover, Table 10 shows that there were high positive correlations between B.W and each of T3, T4 hormones, and Chol .While, there were negative correlations between B.W and each of Lept, LH, FSH hormones and Ca.

High positive correlations were observed between Lept and each of $\mathrm{LH}, \mathrm{FSH}_{\text {, }}$ $\mathrm{Ca}$ and $\mathrm{P}(\mathrm{P}<0.01)$.

Also, there was positive correlation between $\mathrm{T} 3$ and $\mathrm{T} 4$.In addition, the same trend was observed between T4 and chol. Whereas, a high negative correlation was found between Leptin hormone and each of T3 and T4 hormones and chol. $(P<0.01)$. Also, there were negative correlations between either of T3 or T4 hormones and each of $\mathrm{LH}$ and $\mathrm{FSH}$ hormones, and high negative correlation $(\mathrm{P}<0.01)$ was found between $\mathrm{T} 4$ hormone and $\mathrm{Ca}$ and $\mathrm{P}(\mathrm{P}<0.01)$. Furthermore, there were no significant correlation between $\mathrm{T} 3$ hormone and chol.

Generally, these results are in harmony with those of Tina et al. (2003) who found a relationship between live body weight and Leptin, thyroid hormones and some egg production traits for laying hens.

\section{CONCLUSION}

In conclusion, the results of the present study proved the relations between Leptin and thyroid hormones with low body weight of laying hens and they have influence on egg quality and egg production traits besides improving the physiological and immunological performance. Therefore, further researches are needed to elucidate the previous mentioned relations especially for the developed chicken strains. 
Table 2. Body weight and feed consumption of Sinai and Mamourah hens classified according to body weight.

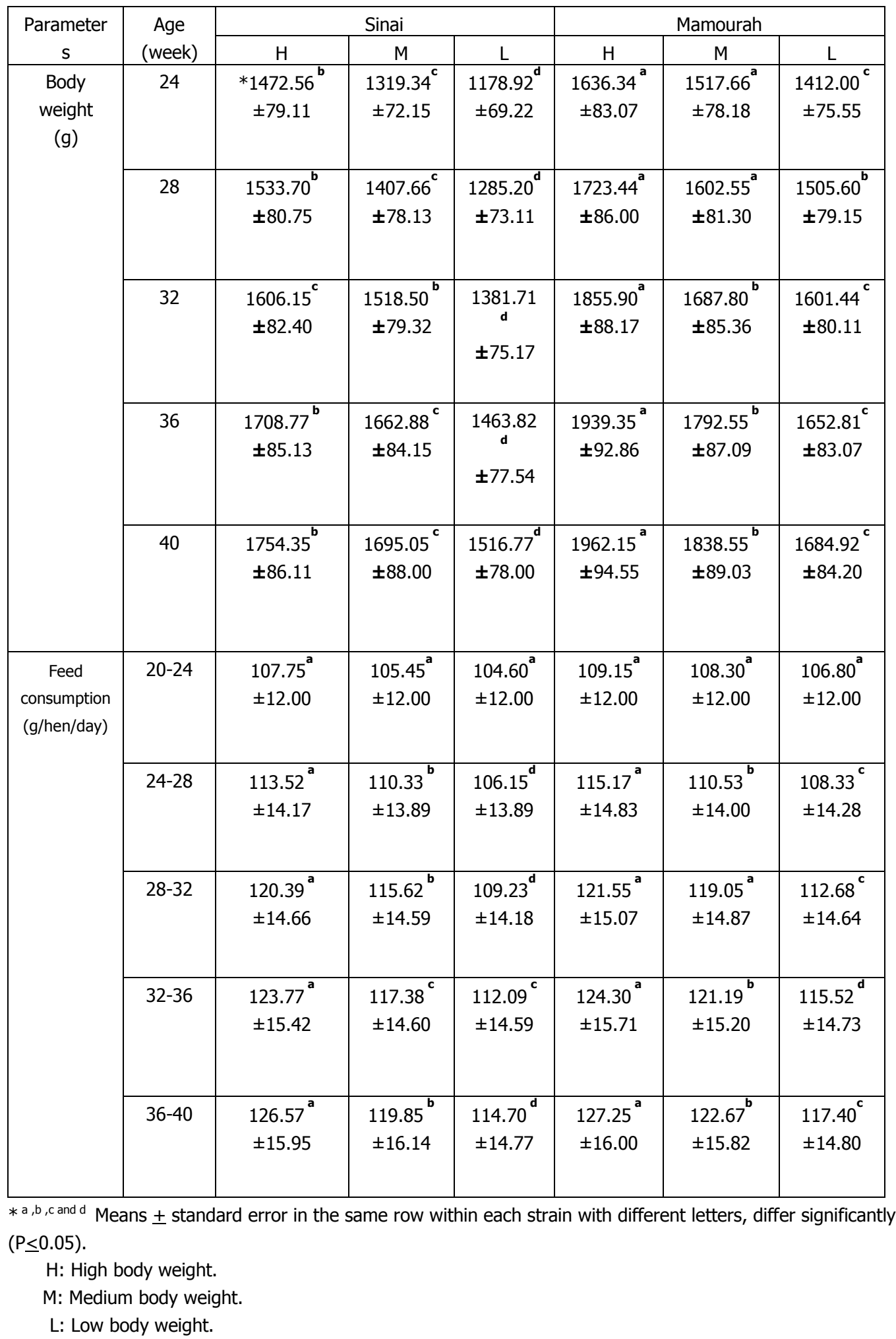


Table 3. Age and body weight at sexual maturity and weight of first egg for Sinai and Mamourah hens classified according to body weight.

\begin{tabular}{|c|c|c|c|c|c|c|}
\hline \multirow[t]{2}{*}{ Parameters } & \multicolumn{3}{|c|}{ Sinai } & \multicolumn{3}{|c|}{ Mamourah } \\
\hline & $\mathrm{H}$ & M & L & $\mathrm{H}$ & $M$ & L \\
\hline $\begin{array}{c}\text { Age at sexual maturity } \\
\text { (day) }\end{array}$ & $\begin{array}{c}* 170.06^{c} \\
\pm 9.11\end{array}$ & $\begin{array}{c}172.15^{\mathbf{b}} \\
\pm 9.11\end{array}$ & $\begin{array}{r}178.47^{\mathrm{a}} \\
\pm 9.11 \\
\end{array}$ & $\begin{array}{c}166.11^{d} \\
\pm 9.11 \\
\end{array}$ & $\begin{array}{r}168.92^{b} \\
\pm 9.11 \\
\end{array}$ & $\begin{array}{c}173.70^{b} \\
\pm 9.11\end{array}$ \\
\hline $\begin{array}{l}\text { Body weight at sexual } \\
\text { maturity }(\mathrm{g})\end{array}$ & $\begin{array}{r}1481.15^{b} \\
\pm 80.22 \\
\end{array}$ & $\begin{array}{r}1323.76^{d} \\
\pm 73.55 \\
\end{array}$ & $\begin{array}{r}1208.80^{e} \\
\pm 71.37 \\
\end{array}$ & $\begin{array}{r}1682.00^{\mathrm{a}} \\
\pm 85.08 \\
\end{array}$ & $\begin{array}{r}1539.07^{b} \\
\pm 79.42 \\
\end{array}$ & $\begin{array}{r}1465.90^{c} \\
\pm 76.60 \\
\end{array}$ \\
\hline Weight of first egg ( $\mathrm{g}$ ) & $\begin{array}{l}38.26^{\mathrm{a}} \\
\pm 1.20\end{array}$ & $\begin{array}{l}36.50^{b} \\
\pm 1.20\end{array}$ & $\begin{array}{l}35.03^{\mathrm{c}} \\
\pm 1.20 \\
\end{array}$ & $\begin{array}{l}39.15^{\mathrm{a}} \\
\pm 1.20\end{array}$ & $\begin{array}{l}37.60^{b} \\
\pm 1.20 \\
\end{array}$ & $\begin{array}{l}36.77^{b} \\
\pm 1.20\end{array}$ \\
\hline
\end{tabular}

$* a, b, c, d$ and $e$ Means \pm standard error in the same row within each strain with different letters, differ significantly $(P \leq 0.05)$.

$\mathrm{H}$ : High body weight.

M: Medium body weight.

L: Low body weight.

Table 4. Egg production traits for Sinai and Mamourah hens classified according to body weight through the experimental periods.

\begin{tabular}{|c|c|c|c|c|c|c|c|}
\hline \multirow[t]{2}{*}{ Parameters } & \multirow{2}{*}{$\begin{array}{l}\text { Period } \\
\text { (week) }\end{array}$} & \multicolumn{3}{|c|}{ Sinai } & \multicolumn{3}{|c|}{ Mamourah } \\
\hline & & $\mathrm{H}$ & $\bar{M}$ & $\mathrm{~L}$ & $\mathrm{H}$ & $M$ & $\mathrm{~L}$ \\
\hline \multirow[t]{5}{*}{$\begin{array}{l}\text { Egg weight } \\
\text { (g) }\end{array}$} & $24-28$ & $\begin{array}{c}* 38.95^{\mathrm{a}} \\
\pm 2.85 \\
\end{array}$ & $\begin{array}{l}37.11^{\mathrm{b}} \\
\pm 2.85\end{array}$ & $\begin{array}{l}36.32^{c} \\
\pm 2.85 \\
\end{array}$ & $\begin{array}{l}40.02^{\mathrm{a}} \\
\pm 2.85 \\
\end{array}$ & $\begin{array}{c}38.55^{\text {ab }} \\
\pm 2.85 \\
\end{array}$ & $\begin{array}{c}37.15^{b} \\
\pm 2.85 \\
\end{array}$ \\
\hline & $28-32$ & $\begin{array}{c}40.06^{b} \\
\pm 3.14\end{array}$ & $\begin{array}{c}39.77^{c} \\
\pm 3.14\end{array}$ & $\begin{array}{l}39.15^{c} \\
\pm 3.14\end{array}$ & $\begin{array}{l}42.50^{\mathrm{a}} \\
\pm 3.14\end{array}$ & $\begin{array}{l}40.36^{b} \\
\pm 3.14\end{array}$ & $\begin{array}{c}40.61^{b} \\
\pm 3.14\end{array}$ \\
\hline & $32-36$ & $\begin{array}{c}42.80^{b} \\
\pm 3.33\end{array}$ & $\begin{array}{l}41.60^{\mathrm{b}} \\
\pm 3.33\end{array}$ & $\begin{array}{l}41.08^{c} \\
\pm 3.33 \\
\end{array}$ & $\begin{array}{l}45.18^{\mathrm{a}} \\
\pm 3.33 \\
\end{array}$ & $\begin{array}{l}44.39^{\mathrm{a}} \\
\pm 3.33 \\
\end{array}$ & $\begin{array}{c}42.03^{b} \\
\pm 3.33 \\
\end{array}$ \\
\hline & $36-40$ & $\begin{array}{l}45.17^{b} \\
\pm 3.60\end{array}$ & $\begin{array}{l}44.95^{\mathrm{b}} \\
\pm 3.60\end{array}$ & $\begin{array}{l}42.57^{c} \\
\pm 3.60\end{array}$ & $\begin{array}{l}48.16^{\mathrm{a}} \\
\pm 3.60\end{array}$ & $\begin{array}{l}46.51^{b} \\
\pm 3.60\end{array}$ & $\begin{array}{l}43.88^{c} \\
\pm 3.60\end{array}$ \\
\hline & $\begin{array}{c}\text { Overall } \\
\text { mean }\end{array}$ & $\begin{array}{c}41.75^{\mathrm{ab}} \\
\pm 3.30\end{array}$ & $\begin{array}{l}40.85^{b} \\
\pm 3.30\end{array}$ & $\begin{array}{l}39.78^{c} \\
\pm 3.30\end{array}$ & $\begin{array}{l}43.97^{\mathrm{a}} \\
\pm 3.30\end{array}$ & $\begin{array}{l}42.45^{\mathrm{a}} \\
\pm 3.30\end{array}$ & $\begin{array}{c}40.92^{b} \\
\pm 3.30\end{array}$ \\
\hline \multirow[t]{5}{*}{$\begin{array}{l}\text { Egg number } \\
\text { (egg/period) }\end{array}$} & $24-28$ & $\begin{array}{l}13.36^{\mathrm{b}} \\
\pm 0.93\end{array}$ & $\begin{array}{l}14.55^{\mathrm{a}} \\
\pm 0.93\end{array}$ & $\begin{array}{l}12.71^{\mathrm{c}} \\
\pm 0.93 \\
\end{array}$ & $\begin{array}{l}14.30^{\mathrm{b}} \\
\pm 0.93\end{array}$ & $\begin{array}{l}15.02^{\mathrm{a}} \\
\pm 0.93 \\
\end{array}$ & $\begin{array}{l}13.41^{\mathrm{b}} \\
\pm 0.93\end{array}$ \\
\hline & $28-32$ & $\begin{array}{l}15.81^{b} \\
\pm 1.05\end{array}$ & $\begin{array}{l}16.20^{\mathrm{b}} \\
\pm 1.05 \\
\end{array}$ & $\begin{array}{l}14.86^{\mathrm{c}} \\
\pm 1.05 \\
\end{array}$ & $\begin{array}{c}16.20^{b} \\
\pm 1.05 \\
\end{array}$ & $\begin{array}{l}17.47^{\mathrm{a}} \\
\pm 1.05 \\
\end{array}$ & $\begin{array}{l}15.93^{b} \\
\pm 1.05 \\
\end{array}$ \\
\hline & $32-36$ & $\begin{array}{l}17.60^{b} \\
\pm 1.41\end{array}$ & $\begin{array}{c}18.37^{\mathrm{b}} \\
\pm 1.41\end{array}$ & $\begin{array}{l}17.20^{\mathrm{b}} \\
\pm 1.41\end{array}$ & $\begin{array}{l}19.91^{\mathrm{a}} \\
\pm 1.41\end{array}$ & $\begin{array}{l}20.36^{\mathrm{a}} \\
\pm 1.41\end{array}$ & $\begin{array}{l}19.05^{\mathrm{a}} \\
\pm 1.41\end{array}$ \\
\hline & $36-40$ & $\begin{array}{c}20.30^{b} \\
\pm 1.62\end{array}$ & $\begin{array}{l}21.76^{\mathrm{a}} \\
\pm 1.62\end{array}$ & $\begin{array}{l}20.01^{b} \\
\pm 1.62\end{array}$ & $\begin{array}{l}21.66^{\mathrm{a}} \\
\pm 1.62\end{array}$ & $\begin{array}{l}22.81^{\mathrm{a}} \\
\pm 1.62\end{array}$ & $\begin{array}{l}21.71^{\mathrm{a}} \\
\pm 1.62\end{array}$ \\
\hline & $\begin{array}{c}\text { Overall } \\
\text { mean }\end{array}$ & $\begin{array}{l}16.76^{c} \\
\pm 1.22 \\
\end{array}$ & $\begin{array}{l}17.72^{\mathrm{b}} \\
\pm 1.22 \\
\end{array}$ & $\begin{array}{l}16.20^{c} \\
\pm 1.22 \\
\end{array}$ & $\begin{array}{l}18.02^{\mathrm{a}} \\
\pm 1.22 \\
\end{array}$ & $\begin{array}{l}18.92^{\mathrm{a}} \\
\pm 1.22 \\
\end{array}$ & $\begin{array}{l}17.52^{\mathrm{b}} \\
\pm 1.22 \\
\end{array}$ \\
\hline \multirow[t]{5}{*}{$\begin{array}{l}\text { Egg mass } \\
(\mathrm{g})\end{array}$} & $24-28$ & $\begin{array}{l}520.37^{b} \\
\pm 21.82 \\
\end{array}$ & $\begin{array}{l}539.95^{\mathrm{a}} \\
\pm 21.82 \\
\end{array}$ & $\begin{array}{l}461.63^{\mathrm{d}} \\
\pm 21.82 \\
\end{array}$ & $\begin{array}{l}572.29^{\mathrm{a}} \\
\pm 21.82 \\
\end{array}$ & $\begin{array}{l}579.02^{a} \\
\pm 21.82 \\
\end{array}$ & $\begin{array}{c}498.18^{c} \\
\pm 21.82 \\
\end{array}$ \\
\hline & $28-32$ & $\begin{array}{l}633.35^{\mathrm{b}} \\
\pm 26.03 \\
\end{array}$ & $\begin{array}{l}644.95^{\mathrm{b}} \\
\pm 26.03 \\
\end{array}$ & $\begin{array}{l}581.77^{c} \\
\pm 26.03\end{array}$ & $\begin{array}{l}688.50^{\mathrm{a}} \\
\pm 26.03 \\
\end{array}$ & $\begin{array}{l}705.09^{\mathrm{a}} \\
\pm 26.03 \\
\end{array}$ & $\begin{array}{l}646.92^{b} \\
\pm 26.03 \\
\end{array}$ \\
\hline & $32-36$ & $\begin{array}{l}753.28^{c} \\
\pm 28.11\end{array}$ & $\begin{array}{l}764.19^{c} \\
\pm 28.11\end{array}$ & $\begin{array}{l}706.58^{d} \\
\pm 28.11\end{array}$ & $\begin{array}{l}899.53^{\mathrm{a}} \\
\pm 28.11 \\
\end{array}$ & $\begin{array}{c}903.85^{\mathrm{a}} \\
\pm 28.11\end{array}$ & $\begin{array}{c}800.67^{b} \\
\pm 28.11\end{array}$ \\
\hline & $36-40$ & $\begin{array}{l}916.95^{c} \\
\pm 29.66\end{array}$ & $\begin{array}{l}978.11^{b} \\
\pm 29.66\end{array}$ & $\begin{array}{l}851.83^{d} \\
\pm 29.66\end{array}$ & $\begin{array}{r}1043.15 \\
a \\
\pm 29.66 \\
\end{array}$ & $\begin{array}{c}1058.00 \\
a \\
\pm 29.66 \\
\end{array}$ & $\begin{array}{l}952.63^{b} \\
\pm 29.66\end{array}$ \\
\hline & $\begin{array}{c}\text { Overall } \\
\text { mean }\end{array}$ & $\begin{array}{l}705.99^{b} \\
\pm 28.55\end{array}$ & $\begin{array}{l}731.80^{b} \\
\pm 28.55\end{array}$ & $\begin{array}{l}650.45^{c} \\
\pm 28.55\end{array}$ & $\begin{array}{l}800.87^{\mathrm{a}} \\
\pm 28.55\end{array}$ & $\begin{array}{l}811.49^{\mathrm{a}} \\
\pm 28.55\end{array}$ & $\begin{array}{l}724.60^{b} \\
\pm 28.55\end{array}$ \\
\hline
\end{tabular}

$* a, b, c$ and $d$ Means \pm standard error in the same row within each strain with different letters, differ significantly $(P \leq 0.05)$.
$\mathrm{H}$ : High body weight.
M: Medium body weight.
L: Low body weight. 
Table 5. Egg quality traits for Sinai and Mamourah hens classified according to body weight.

\begin{tabular}{|c|c|c|c|c|c|c|}
\hline \multirow[t]{2}{*}{ Parameters } & \multicolumn{3}{|c|}{ Sinai } & \multicolumn{3}{|c|}{ Mamourah } \\
\hline & $\mathrm{H}$ & M & $\mathrm{L}$ & $\mathrm{H}$ & $M$ & $\mathrm{~L}$ \\
\hline Shape & $* 67.95^{\mathrm{a}}$ & $68.17^{a}$ & $67.88^{a}$ & $68.55^{a}$ & $69.23^{a}$ & $68.11^{a}$ \\
\hline Index & \pm 3.15 & \pm 3.15 & \pm 3.15 & \pm 3.15 & \pm 3.15 & \pm 3.15 \\
\hline Yolk & $50.11^{a}$ & $49.92^{a}$ & $49.56^{a}$ & $50.23^{a}$ & $49.81^{a}$ & $49.78^{a}$ \\
\hline Index & \pm 2.30 & \pm 2.30 & \pm 2.30 & \pm 2.30 & \pm 2.30 & \pm 2.30 \\
\hline Yolk & $15.96^{\mathrm{a}}$ & $15.80^{\mathrm{a}}$ & $15.41^{\mathrm{a}}$ & $16.03^{a}$ & $15.88^{a}$ & $15.48^{\mathrm{a}}$ \\
\hline weight (g) & \pm 1.10 & \pm 1.10 & \pm 1.10 & \pm 1.10 & \pm 1.10 & \pm 1.10 \\
\hline Albumen & $23.46^{\mathrm{ab}}$ & $22.80^{\mathrm{ab}}$ & $22.55^{b}$ & $25.92^{a}$ & $23.71^{\text {ab }}$ & $22.18^{b}$ \\
\hline weight (g) & \pm 1.44 & \pm 1.44 & \pm 1.44 & \pm 1.44 & \pm 1.44 & \pm 1.44 \\
\hline Shell & $6.75^{a}$ & $6.35^{a}$ & $6.61^{a}$ & $6.93^{a}$ & $6.72^{a}$ & $6.22^{a}$ \\
\hline weight (g) & \pm 0.54 & \pm 0.54 & \pm 0.54 & \pm 0.54 & \pm 0.54 & \pm 0.54 \\
\hline Shell & $15.35^{a}$ & $13.61^{a}$ & $13.75^{\mathrm{a}}$ & $14.19^{\mathrm{a}}$ & $14.52^{\mathrm{a}}$ & $14.44^{\mathrm{a}}$ \\
\hline weight (\%) & \pm 0.95 & \pm 0.95 & \pm 0.95 & \pm 0.95 & \pm 0.95 & \pm 0.95 \\
\hline Yolk & $34.57^{b}$ & $35.76^{a}$ & $36.19^{a}$ & $33.79^{b}$ & $34.29^{b}$ & $35.88^{a}$ \\
\hline weight (\%) & \pm 1.82 & \pm 1.82 & \pm 1.82 & \pm 1.82 & \pm 1.82 & \pm 1.82 \\
\hline Albumen & $50.08^{b}$ & $50.92^{a}$ & $50.06^{b}$ & $52.02^{a}$ & $51.19^{a}$ & $49.68^{b}$ \\
\hline weight (\%) & \pm 2.02 & \pm 2.02 & \pm 2.02 & \pm 2.02 & \pm 2.02 & \pm 2.02 \\
\hline Shell & $0.305^{b}$ & $0.374^{\mathrm{a}}$ & $0.390^{a}$ & $0.315^{b}$ & $0.362^{a}$ & $0.388^{a}$ \\
\hline $\begin{array}{l}\text { thickness } \\
(\mathrm{mm})\end{array}$ & \pm 0.03 & \pm 0.03 & \pm 0.03 & \pm 0.03 & \pm 0.03 & \pm 0.03 \\
\hline Haugh & $86.00^{b}$ & $87.00^{b}$ & $88.00^{a}$ & $85.00^{c}$ & $86.00^{b}$ & $88.00^{a}$ \\
\hline units & \pm 2.13 & \pm 2.13 & \pm 2.13 & \pm 2.13 & \pm 2.13 & \pm 2.13 \\
\hline
\end{tabular}

$*$ a and $\mathrm{b}$ Means \pm standard error in the same row within each strain with different letters, differ significantly $(\mathrm{P} \leq 0.05)$.

$\mathrm{H}$ : High body weight.

M: Medium body weight.

L: Low body weight. 

IMMUNOLOGICAL PERFORMANCE OF TWO LOCAL LAYING HENS STRAINS

Table 6. Serum hormones for Sinai and Mamourah hens classified according to body weight at end of the experimental period.

\begin{tabular}{|c|c|c|c|c|c|c|}
\hline \multirow[t]{2}{*}{ Parameters } & \multicolumn{3}{|c|}{ Sinai } & \multicolumn{3}{|c|}{ Mamourah } \\
\hline & $\mathrm{H}$ & M & $\mathrm{L}$ & $\mathrm{H}$ & M & L \\
\hline Leptin & $* 1.342^{c}$ & $* 1.507^{b}$ & $1.826^{\mathrm{a}}$ & $1.230^{c}$ & $1.685^{\mathrm{ab}}$ & $1.752^{\mathrm{a}}$ \\
\hline$(\mathrm{ng} / \mathrm{ml})$ & \pm 0.15 & \pm 0.15 & \pm 0.15 & \pm 0.15 & \pm 0.15 & \pm 0.15 \\
\hline T3 & $155.00^{a}$ & $137.40^{b}$ & $109.00^{c}$ & $155.20^{a}$ & $138.80^{b}$ & $100.40^{\mathrm{c}}$ \\
\hline$(\mathrm{ng} / \mathrm{ml})$ & \pm 5.37 & \pm 5.37 & \pm 5.37 & \pm 5.37 & \pm 5.37 & \pm 5.37 \\
\hline T4 & $475.15^{a}$ & $450.00^{b}$ & $373.00^{c}$ & $482.11^{a}$ & $456.00^{b}$ & $372.00^{c}$ \\
\hline$(\mathrm{ng} / \mathrm{ml})$ & \pm 11.55 & \pm 11.55 & \pm 11.55 & \pm 11.55 & \pm 11.55 & \pm 11.55 \\
\hline Ratio & $3.065^{c}$ & $3.275^{b}$ & $3.422^{b}$ & $3.106^{c}$ & $3.285^{b}$ & $3.705^{\mathrm{a}}$ \\
\hline T3:T4 & \pm 0.04 & \pm 0.06 & \pm 0.03 & \pm 0.04 & \pm 0.05 & \pm 0.08 \\
\hline LH & $0.326^{c}$ & $0.435^{b}$ & $0.770^{\mathrm{a}}$ & $0.400^{b}$ & $0.466^{b}$ & $0.791^{\mathrm{a}}$ \\
\hline (IU/ml) & \pm 0.03 & \pm 0.04 & \pm 0.06 & \pm 0.04 & \pm 0.05 & \pm 0.06 \\
\hline FSH & $1.553^{c}$ & $1.941^{b}$ & $2.428^{a}$ & $1.650^{c}$ & $2.023^{b}$ & $2.622^{\mathrm{a}}$ \\
\hline (IU/ml) & \pm 0.12 & \pm 0.12 & \pm 0.15 & \pm 0.12 & \pm 0.13 & \pm 0.14 \\
\hline
\end{tabular}

$* \mathrm{a}, \mathrm{b}$ and $\mathrm{c}$ Means \pm standard error in the same row within each strain with different letters, differ significantly $(P \leq 0.05)$.

H: High body weight.

M: Medium body weight.

L: Low body weight. 
Table 7. Serum constituents for Sinai and Mamourah hens classified according to body weight at end of the experimental period.

\begin{tabular}{|c|c|c|c|c|c|c|}
\hline \multirow[t]{2}{*}{ Parameters } & \multicolumn{3}{|c|}{ Sinai } & \multicolumn{3}{|c|}{ Mamourah } \\
\hline & $\mathrm{H}$ & M & $\mathrm{L}$ & $\mathrm{H}$ & M & $\mathrm{L}$ \\
\hline Calcium & $* 11.45^{\mathbf{b}}$ & $13.66^{a}$ & $14.55^{\mathrm{a}}$ & $11.17^{b}$ & $13.31^{\mathrm{a}}$ & $13.38^{a}$ \\
\hline$(\mathrm{mg} / \mathrm{dl})$ & \pm 1.42 & \pm 1.42 & \pm 1.42 & \pm 1.42 & \pm 1.42 & \pm 1.42 \\
\hline Phosphorus & $4.33^{c}$ & $5.57^{b}$ & $6.08^{\mathrm{a}}$ & $5.61^{b}$ & $5.73^{b}$ & $6.15^{\mathrm{a}}$ \\
\hline$(\mathrm{mg} / \mathrm{dl})$ & \pm 0.32 & \pm 0.32 & \pm 0.32 & \pm 0.32 & \pm 0.32 & \pm 0.32 \\
\hline Total protein & $4.85^{c}$ & $4.96^{\mathrm{c}}$ & $5.38^{b}$ & $4.71^{c}$ & $5.53^{b}$ & $6.19^{\mathrm{a}}$ \\
\hline$(\mathrm{g} / \mathrm{dl})$ & \pm 0.29 & \pm 0.29 & \pm 0.29 & \pm 0.29 & \pm 0.29 & \pm 0.29 \\
\hline Albumin & $3.11^{b}$ & $3.20^{b}$ & $3.47^{\mathrm{ab}}$ & $3.09^{c}$ & $3.72^{\mathrm{ab}}$ & $4.13^{\mathrm{a}}$ \\
\hline$(\mathrm{g} / \mathrm{dl})$ & \pm 0.25 & \pm 0.25 & \pm 0.25 & \pm 0.25 & \pm 0.25 & \pm 0.25 \\
\hline Globulin & $1.74^{\mathrm{ab}}$ & $1.76^{\mathrm{ab}}$ & $1.91^{\mathrm{a}}$ & $1.62^{b}$ & $1.81^{\mathrm{a}}$ & $2.06^{\mathrm{a}}$ \\
\hline$(\mathrm{g} / \mathrm{dl})$ & \pm 0.09 & \pm 0.09 & \pm 0.09 & \pm 0.09 & \pm 0.09 & \pm 0.09 \\
\hline Glucose & $182.73^{a}$ & $169.15^{b}$ & $165.77^{b}$ & $178.11^{\mathrm{a}}$ & $167.00^{b}$ & $156.80^{c}$ \\
\hline$(\mathrm{mg} / \mathrm{dl})$ & \pm 6.22 & \pm 6.22 & \pm 6.22 & \pm 6.22 & \pm 6.22 & \pm 6.22 \\
\hline Cholesterol & $212.39^{\mathrm{a}}$ & $163.21^{b}$ & $153.66^{b}$ & $225.97^{\mathrm{a}}$ & $160.89^{b}$ & $125.37^{c}$ \\
\hline$(\mathrm{mg} / \mathrm{dl})$ & \pm 5.71 & \pm 5.71 & \pm 5.71 & \pm 5.71 & \pm 5.71 & \pm 5.71 \\
\hline LDL & $145.41^{\mathrm{a}}$ & $119.18^{b}$ & $118.80^{b}$ & $151.02^{\mathrm{a}}$ & $113.62^{b}$ & $84.11^{\mathrm{c}}$ \\
\hline$(\mathrm{mg} / \mathrm{dl})$ & \pm 3.07 & \pm 3.07 & \pm 3.07 & \pm 3.07 & \pm 3.07 & \pm 3.07 \\
\hline HDL & $66.98^{\mathrm{a}}$ & $44.03^{b}$ & $34.86^{c}$ & $74.95^{a}$ & $47.27^{b}$ & $41.26^{c}$ \\
\hline$(\mathrm{mg} / \mathrm{dl})$ & \pm 2.66 & \pm 2.66 & \pm 2.66 & \pm 2.66 & \pm 2.66 & \pm 2.66 \\
\hline Total lipids & $741.22^{a}$ & $687.08^{b}$ & $593.54^{c}$ & $720.54^{a}$ & $665.38^{b}$ & $638.80^{b}$ \\
\hline$(\mathrm{mg} / \mathrm{dl})$ & \pm 13.28 & \pm 13.28 & \pm 13.28 & \pm 13.28 & \pm 13.28 & \pm 13.28 \\
\hline
\end{tabular}

$* a, b$ and $c$ Means \pm standard error in the same row within each strain with different letters, differ significantly $(P \leq 0.05)$.

H: High body weight.

M: Medium body weight.

L: Low body weight. 

IMMUNOLOGICAL PERFORMANCE OF TWO LOCAL LAYING HENS STRAINS

Table 8. Immune response against Newcastle Disease Virus (NDV) and Avian Influenza Disease Virus (AIDV) for Sinai and Mamourah hens classified according to body weight at end of the experimental period.

\begin{tabular}{|c|c|c|c|c|c|c|}
\hline \multirow{2}{*}{$\begin{array}{l}\text { Immune } \\
\text { response }\end{array}$} & \multicolumn{3}{|c|}{ Sinai } & \multicolumn{3}{|c|}{ Mamourah } \\
\hline & $\mathrm{H}$ & M & L & $\mathrm{H}$ & M & L \\
\hline $\begin{array}{c}\text { Against } \\
\text { NDV }\end{array}$ & $\begin{array}{c}* 148.18{ }^{c} \\
\pm 10.15\end{array}$ & $\begin{array}{c}169.55^{b} \\
\pm 10.15\end{array}$ & $\begin{array}{c}186.30^{a} \\
\pm 10.15\end{array}$ & $\begin{array}{l}151.09^{c} \\
\pm 10.15\end{array}$ & $\begin{array}{c}172.88^{b} \\
\pm 10.15\end{array}$ & $\begin{array}{l}192.15^{\mathrm{a}} \\
\pm 10.15\end{array}$ \\
\hline $\begin{array}{c}\text { Against } \\
\text { AIDV }\end{array}$ & $\begin{array}{l}6.28^{c} \\
\pm 1.17\end{array}$ & $\begin{array}{l}8.54^{\mathrm{a}} \\
\pm 1.17\end{array}$ & $\begin{array}{l}8.71^{a} \\
\pm 1.17\end{array}$ & $\begin{array}{l}6.78^{c} \\
\pm 1.17\end{array}$ & $\begin{array}{l}8.06^{b} \\
\pm 1.17\end{array}$ & $\begin{array}{l}9.00^{\mathrm{a}} \\
\pm 1.17\end{array}$ \\
\hline
\end{tabular}

$* a$, b and $c$ Means \pm standard error in the same row within each strain with different letters, differ significantly $(P \leq 0.05)$.

$\mathrm{H}$ : High body weight.

M: Medium body weight.

L: Low body weight.

Table 9. Live body weight, carcass weight and relative organs weights for Sinai and Mamourah hens classified according to body weight at end of the experimental period.

\begin{tabular}{|c|c|c|c|c|c|c|}
\hline \multirow[t]{2}{*}{ Parameters } & \multicolumn{3}{|c|}{ Sinai } & \multicolumn{3}{|c|}{ Mamourah } \\
\hline & $\mathrm{H}$ & $M$ & $\mathrm{~L}$ & $\mathrm{H}$ & M & $\mathrm{L}$ \\
\hline $\begin{array}{l}\text { Body weight } \\
\text { (g) }\end{array}$ & $\begin{array}{c}* 1728.55^{b} \\
\pm 15.66 \\
\end{array}$ & $\begin{array}{c}1657.11^{c} \\
\pm 15.66\end{array}$ & $\begin{array}{c}1471.88^{d} \\
\pm 15.66 \\
\end{array}$ & $\begin{array}{c}1926.30^{\mathrm{a}} \\
\pm 15.66 \\
\end{array}$ & $\begin{array}{c}1786.07^{\mathbf{b}} \\
\pm 15.66 \\
\end{array}$ & $\begin{array}{c}1675.91^{\mathrm{c}} \\
\pm 15.66 \\
\end{array}$ \\
\hline $\begin{array}{c}\text { Carcass weight } \\
\text { (g) }\end{array}$ & $\begin{array}{c}1240.84^{\mathrm{a}} \\
\pm 9.18\end{array}$ & $\begin{array}{c}1193.69^{b} \\
\pm 9.18\end{array}$ & $\begin{array}{c}991.44^{b} \\
\pm 9.18\end{array}$ & $\begin{array}{c}1281.35^{\mathrm{a}} \\
\pm 9.18\end{array}$ & $\begin{array}{c}1168.86^{b} \\
\pm 9.18\end{array}$ & $\begin{array}{c}1105.10^{c} \\
\pm 9.18\end{array}$ \\
\hline Liver \% & $\begin{array}{l}2.16^{\mathrm{c}} \\
\pm 0.33\end{array}$ & $\begin{array}{l}3.57^{\mathrm{a}} \\
\pm 0.33\end{array}$ & $\begin{array}{l}3.72^{\mathrm{a}} \\
\pm 0.33\end{array}$ & $\begin{array}{l}2.63^{b} \\
\pm 0.33\end{array}$ & $\begin{array}{l}2.80^{b} \\
\pm 0.33\end{array}$ & $\begin{array}{l}3.61^{a} \\
\pm 0.33\end{array}$ \\
\hline Heart \% & $\begin{array}{l}0.75^{\mathrm{a}} \\
\pm 0.05\end{array}$ & $\begin{array}{l}0.69^{\mathrm{a}} \\
\pm 0.05\end{array}$ & $\begin{array}{l}0.61^{\mathrm{a}} \\
\pm 0.05\end{array}$ & $\begin{array}{l}0.77^{\mathrm{a}} \\
\pm 0.05\end{array}$ & $\begin{array}{l}0.71^{\mathrm{a}} \\
\pm 0.05\end{array}$ & $\begin{array}{l}0.62^{\mathrm{a}} \\
\pm 0.05\end{array}$ \\
\hline Kidney \% & $\begin{array}{l}1.01^{\mathrm{a}} \\
\pm 0.07\end{array}$ & $\begin{array}{l}0.96^{\mathrm{a}} \\
\pm 0.07 \\
\end{array}$ & $\begin{array}{l}0.85^{\mathrm{b}} \\
\pm 0.07\end{array}$ & $\begin{array}{l}1.12^{\mathrm{a}} \\
\pm 0.07\end{array}$ & $\begin{array}{l}0.98^{\mathrm{a}} \\
\pm 0.07\end{array}$ & $\begin{array}{l}0.87^{b} \\
\pm 0.07\end{array}$ \\
\hline Gizzard \% & $\begin{array}{l}2.97^{\mathrm{a}} \\
\pm 0.26\end{array}$ & $\begin{array}{l}2.61^{b} \\
\pm 0.26\end{array}$ & $\begin{array}{l}2.36^{\mathrm{c}} \\
\pm 0.26\end{array}$ & $\begin{array}{l}3.01^{\mathrm{a}} \\
\pm 0.26\end{array}$ & $\begin{array}{l}2.75^{b} \\
\pm 0.26\end{array}$ & $\begin{array}{l}2.35^{\mathrm{c}} \\
\pm 0.26\end{array}$ \\
\hline $\begin{array}{c}\text { Abdominal fat } \\
\%\end{array}$ & $\begin{array}{l}2.21^{a} \\
\pm 0.21\end{array}$ & $\begin{array}{l}1.81^{b} \\
\pm 0.21\end{array}$ & $\begin{array}{l}1.27^{\mathrm{c}} \\
\pm 0.21\end{array}$ & $\begin{array}{l}2.38^{\mathrm{a}} \\
\pm 0.21\end{array}$ & $\begin{array}{l}1.93^{b} \\
\pm 0.21\end{array}$ & $\begin{array}{l}1.32^{c} \\
\pm 0.21\end{array}$ \\
\hline Spleen \% & $\begin{array}{l}0.23^{c} \\
\pm 0.03\end{array}$ & $\begin{array}{l}0.26^{b} \\
\pm 0.03\end{array}$ & $\begin{array}{l}0.29^{\mathrm{a}} \\
\pm 0.03\end{array}$ & $\begin{array}{l}0.27^{\mathbf{b}} \\
\pm 0.03\end{array}$ & $\begin{array}{l}0.27^{b} \\
\pm 0.03\end{array}$ & $\begin{array}{l}0.30^{\mathrm{a}} \\
\pm 0.03\end{array}$ \\
\hline Thymus \% & $\begin{array}{l}0.30^{\mathrm{c}} \\
\pm 0.04\end{array}$ & $\begin{array}{l}0.35^{b} \\
\pm 0.04\end{array}$ & $\begin{array}{l}0.38^{\mathrm{a}} \\
\pm 0.04\end{array}$ & $\begin{array}{l}0.31^{\mathrm{c}} \\
\pm 0.04\end{array}$ & $\begin{array}{l}0.34^{\mathrm{b}} \\
\pm 0.04\end{array}$ & $\begin{array}{l}0.40^{\mathrm{a}} \\
\pm 0.04\end{array}$ \\
\hline
\end{tabular}

$* a$, b and $c$ Means \pm standard error in the same row within each strain with different letters, differ significantly $(P \leq 0.05)$.

$\mathrm{H}$ : High body weight.

M: Medium body weight.

L: Low body weight. 
Table 10. Phenotypic correlation between body weight and some productive and physiological performance parameters between average of Sinai and Mamourah hens classified according to body weight at the end of experimental period.

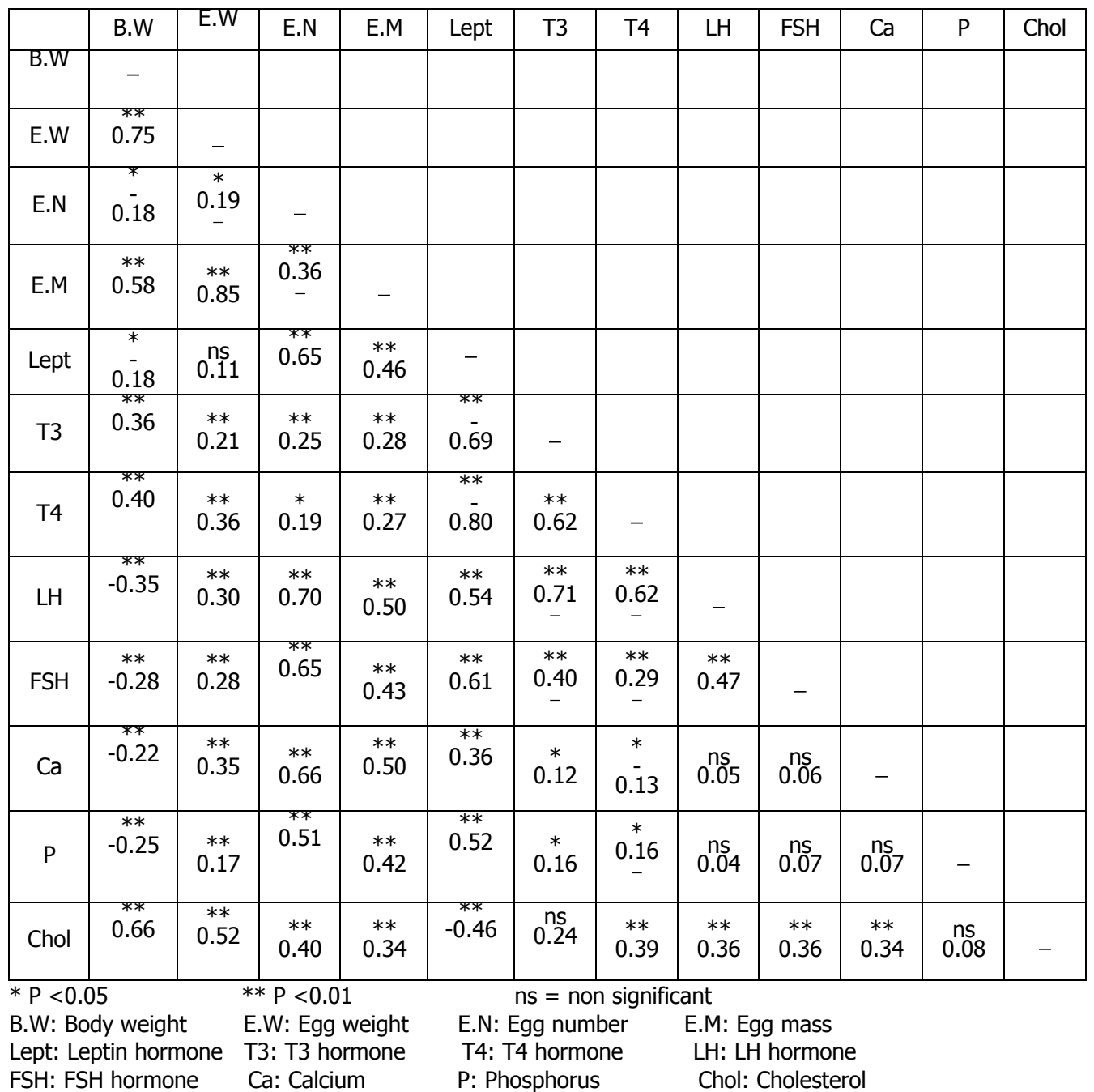

\section{REFERENCES}

1. Ashwell, C. M., S. M. Czerwinski, D. M. Brocht and J. P. Mcmurtry. 1999. Hormonal regulation of leptin expression in broiler chickens. Journal of Physiology.276: 226- 232.

2. Bruggeman. V., O. M. Onagbesan and E. Decuypere. 2007. Body weight, fat content, liver weight and plasma leptin concentrations in broiler breeder females reared under ad-libitum feeding, restricted feeding or combinations of both until age of first egg. Journal of Reproductive Endocrinology.33:557-569.

3. Cassy. S., P. M.S. Crochet, M. Derouet, D. H. Keisler and M. Taouis. 2004. Peripheral leptin effect on feed intake in young chickens as influenced by age and strain. Domest. Anim. Endocrinal. : 27:51-61.

4. Christos. S. M. and J. M. Stergios. 1998. Leptin: in search of role (s) in Chicken physiology and pathophysiology. Clinical Endocrinology.49:551-567. 
5. El-Labban. A. F. M. 2000.Evaluation of egg quality traits in four locally developed strains chickens. Proc. Conf. Anim. Prod. In The 21th Century, Sakha.359-366.

6. Emmerson, D.A. 2003. Breeding objectives and selection strategies for broiler production. Pages 113-126 in poultry Genetics. Breeding and Biotechnology. W. M. Muir and S. E. Aggrey, eds. CABI Publishing, Wallingford. UK.

7. Foster, D. L. and S. Nugatani. 1999. Physiological perspectives on leptin as a regulator of reproduction: role in timing puberty. Biology of Reproduction. 60: 205- 215.

8. Hanafi, M.S. and A. Obeidah 1984. Genetic and phenotypic parameters of the egg shell thickness in Fayoumi and Rhode Island Reds. Animals of Agric., Sci., Moshtohor. 21: 377-384.

9. Hassan .M .S. H; S .M .M.EL-Soudany and Kh. Roushdy. 2006. Relationship between parathyroid, calcitonin hormones and productive, Physiological and immunological performance of some local strains .Egypt. Poult. Sci. 26:297317.

10. Hassaan. S.F., S.A. Abdel-Fattah, A. E. Elsalmoney and M .S. H. Hassan. 2009. Relationship between some serum enzyme activities, liver functions and body weight in growing local chickens. International Journal of Poultry Science. 7:700-705.

11. Jenni, H. 2007. Leptin: a diverse regulator of neuronal function. Journal of Neurochemistry.100: 307 -313.

12. Kosba .M. A. and AbdEl-Halim .H. A. H. 2008. Evaluation of the Egyptian local strains of chicks. Egypt. Poult. Sci. 28:1239-1251.

13. Kuo, A.Y. 2003. Genomic and physiological differences for Ghrelin and Leptin receptor in lines of chickens selected for high and low body weight. J. Animal and Poultry Sciences: 1-12.

14. Marie. Y. A., M. A. Ibrahim., M. A. Mahmoud and H. A. Aboukhashaba. 2009. Influence of nutrient density on productive and reproductive performance of some local laying hen strains. Egypt. Poult. Sci.:529-564.

15. OIE manual. 2005. Manual of Diagnostic Tests and Vaccines for Terrestrial Animals .PART 2S ECTION 2.1.Chapter.

16. Ricklefs, R. E. 1985. Modification of growth and development of muscles of poultry. Poult. Sci. 64:1563-1576.

17. SAS Institute 2000. SAS. Users Guide, Version 6.12. SAS Institute, Cary. NC. U.S.A.

18. Singh, H. and A. W. Nordskog, 1982. Significance of body weight as a performance parameter. Poult. Sci. 61:1933-1938.

19. Spiegelman, B. M. and J. S. Flier. 2001. Obesity and the regulation of energy balance. Journal of Cell Science.104:531-543.

20. Tina. Z. B., G.N. Brabant. J. J. Holst. and U. R. Feldt. 2003. Circulating leptin and thyroid dysfunction. European Journal of Endocrinology. 149:257-271. 
دراسة العلاقة بين وزن الجسم وبعض الهرمونات و الأداء الاتتاجى والفسيولوجى

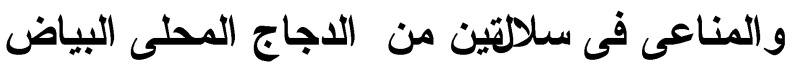

\section{مجدى سيد حسن حسن ، ايهاب أحمد عبدالله ، دعاء محمد محمد يس}

قسم بحوث تربية الدو/جن ـ معهل بحوث الإنتاج الحبواني ـ وزارة الزراعة ـ الدقي ـ الجبزة ـ مصر.

تم وزن إجمالى قطيع المحطة من الاناث لسلالتى سيناء و المعمورة عند عمر 20 أسبوع وحسب متوسط الوزن 土ـ الانحر اف القياسى لكل سلالة على حدة وبناء على ذلك تم اخذ أجمالى عدد 300

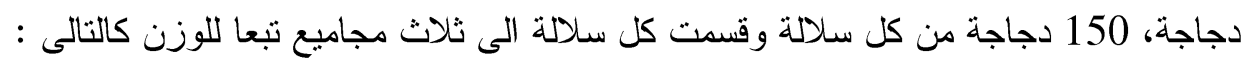

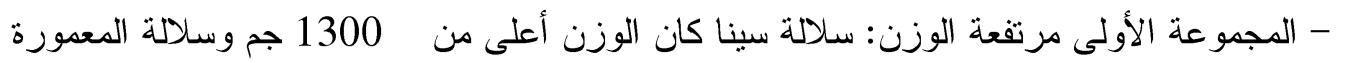

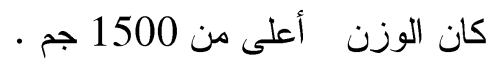
- المجموعة الثانية متوسطة الوزن : سلالة سينا كان الوزن بين

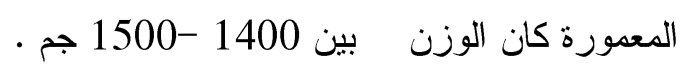

- المجموعة الثالثة منخفضة الوزن: سلالة سينا كان الوزن أقل من 1200 جم وسلالة المعمورة كان

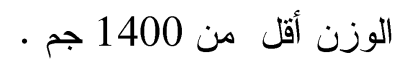

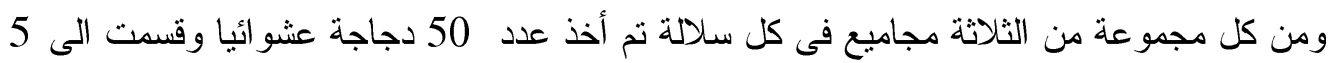
مكررات وتم تربيتهم حتى عمر 40 أسبوع تحت نفس الظروف من التزبية على الارض وض والحرارة و الاضاءة و التهوية ونفس العليقة ، وخلال فتر ة التجربة تم أخذ القياسات الاتية :

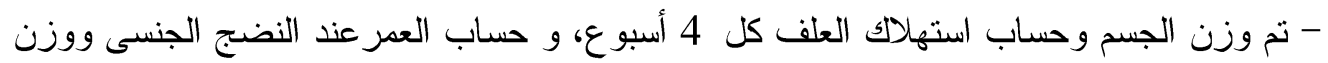
أول بيضة و الوزن عند النضج الجنسى وتسجيل عدد ووزن البيض وتم حساب كتلة البيض يوميا

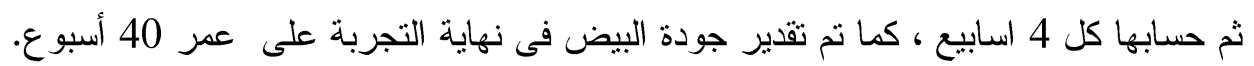

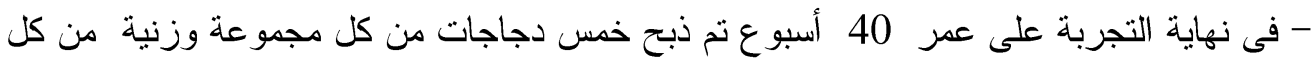

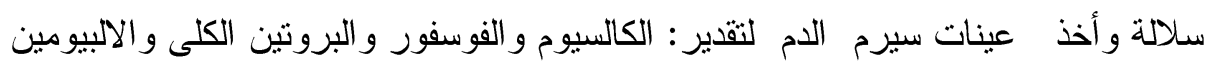

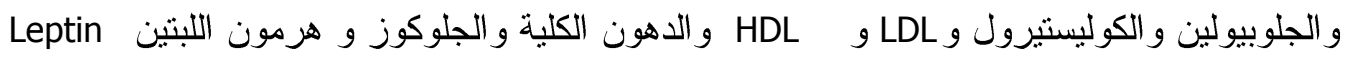

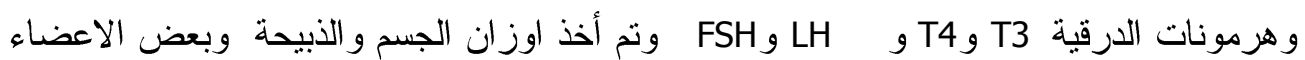

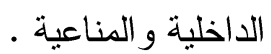
- كما أخذت عينات دم فى عمر 40أسبوع لتقدير الاستجابة المناعية ضد مرضى النيوكاسيل

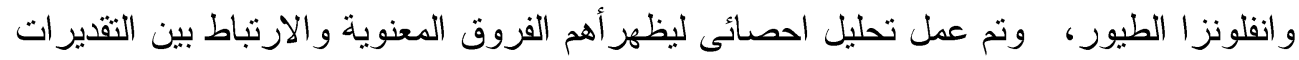

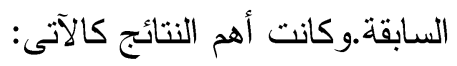
- كانت المجاميع مرتفعة الوزن فى كلا السلاتين الاعلى فى استهلاكك العلف من المجاميع المتوسطة و المنخفضة الوزن ،وكانت سلالة المعمورة الاكثر وزنا و الاكثر إستهلاكا للعلف من سلالة سيناخلال 
- فى المجاميع الوزنية منخفضة الوزن تأخر عمر النضج الجنسى مع زيادة عدد وكتلة البيض بعد

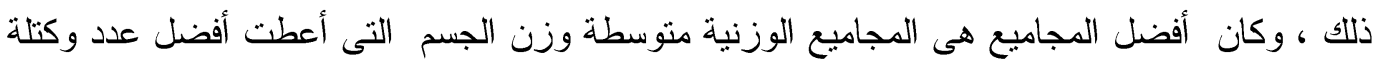

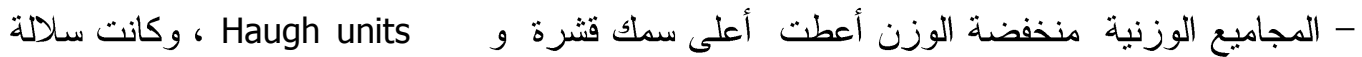
المعدورة اعلى فى وزن البياض المطلق و النسبى بالمقارنة بسلالة سينا ، ولم يوجد فروق معنوية فى اعى لهون

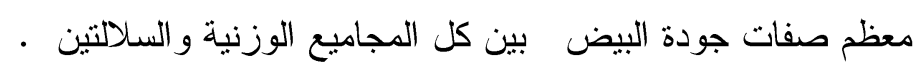
- ز زاد مستوى كلا من هرمون اللبتين وهرمونات الدرقية و الكالسيوم و الفوسفورو البروتين الكلى لئل

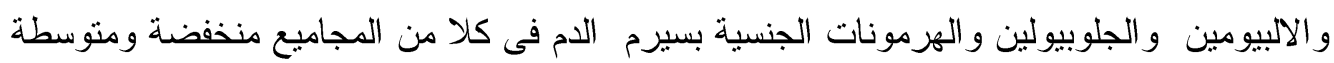

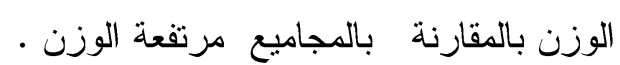

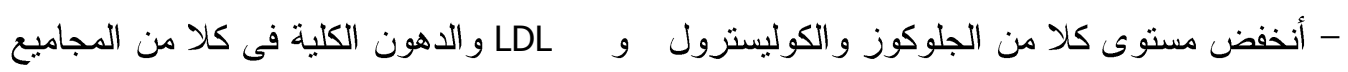

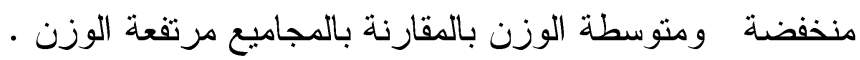

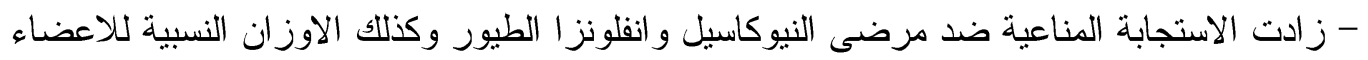

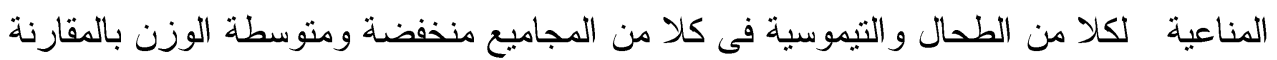

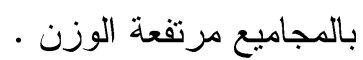
- كان هنالك أرتباط معنويا وأيجابيا بين وزن الجسم ووزن ونت وكتلة البيض ولكنة كان معنويا وسلبيا بين

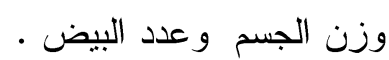

- كان هناك أرتباط معنويا و أيجابيا بين وزن الجسم وكلا من هرمونى الدرقية T3 ، T4 و الكوليستيرول

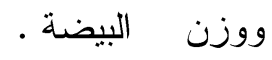

FSH, LH - كان هناك أرتباط معنويا وسلبيا بين وزن الجسم وكلا من هرمونات اللبتين و

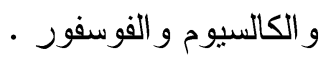
- وجد أرتباط بين ارتفاع مستوى هرمون اللبتنين وأنخفاض مستوى كلا من هرمونى الدرقية .T4 g T3

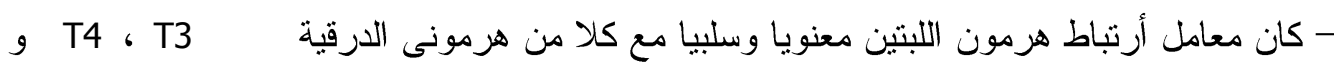
الكوليستبرول. - كان معامل أرتباط هرمون اللبتين معنويا وأيجابيا مع كلا من هرمونى FHH و FH و الكالسيوم و الفوسفور - مان معام وتوضح نتائج الدر اسة الحاجة الى مزيد من الأبحاث عن علاقة هرمون اللبتين وهرمونات الغدة

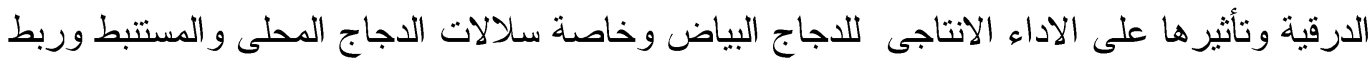

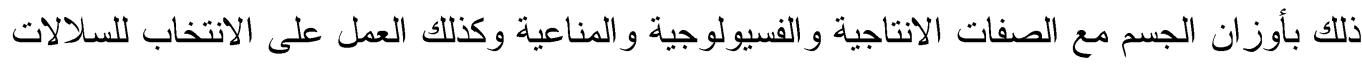

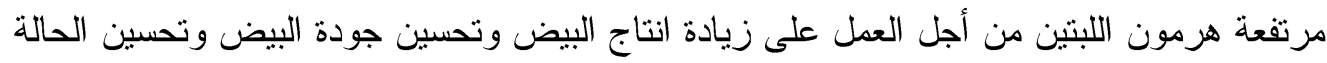

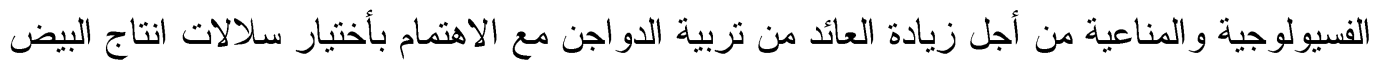
خفيفة ومتوسطة الوزن لزيادة المنتج و العائد. 